EESTI NSV TEADUSTE AKADEEMIA TOIMETISED. GEOLOOGIA

ИЗВЕСТИЯ АКАДЕМИИ НАУК ЭСТОНСКОП ССР. ГЕОЛОГИЯ

PROCEEDINGS OF THE ACADEMY OF SCIENCES OF -THE ESTONIAN SSR. GEOLOGY

1986. 35.4

удК $552.124 .3: 549(474.2)$

Mape $\mathrm{KOHCA}$

\title{
ЦИРКОН В ДОВЕНДСКОЙ КОРЕ ВЫВЕТРИВАНИЯ КРИСТАЛЛИЧЕСКИХ ПОРОД ЭСТОНИИ
}

По результатам специального исследования автором ранее описаны типоморфные особенности циркона главных типов свежих, невыветрелых метаморфических, метасоматических и интрузивных пород докембрийского кристаллического фундамента Северной Прибалтики (Конса, 1985). В настоящем сообщении рассматривается поведение циркона в профиле коры выветривания на фундаменте по результатам изучения 45 проб из 15 буровых скважин. Этими скважинами вскрыты характерные для фундамента ассоциации пород (см. табл. 1 в статье Конса, 1986): 1) архейские метаморфические породы (биотит-амфибол-пироксеновые и двупироксеңовые гнейсы, гранитогнейсы, биотит-амфиболовые рнейсы) ; 2) нижнепротерозойские метаморфические породы (амфиболиты, биотитовые плагиогнейсы, глиноземистые гнейсы); 3) чарнокиты и мигматитобразующие граниты (чарнокиты, теневые граниты или теневые мигматиты, плагиограниты, плагиомикроклиновые граниты) ; 4) интрузивные послескладчатые граниты (порфировидные калиевые граниты, рапакиви-граниты).

Закономерности изменения горных пород по профилю коры выветривания на кристаллическом фундаменте охарактеризованы Т. Кууспалу и др. (1971), В. Ванамб и др. (1977). По интенсивности гипергенных изменений пород указанные авторы выделили четыре степени выветривания, обозначив их (по мере нарастания изменений) 0, I, II, III (Кристаллический ..., 1983).

В профиле 0-II степени постепенно нарастает роль псевдоморфизации породообразующих минералов и уменьшается их прочность при сохранении исходных структур и текстур. Породы III степени выветривания разрыхленные, существенно глинистые. Материнские породы, лишившиеся исходной структуры и текстуры, узнаваемы с трудом. По минеральному составу глинистого вещества кора выветривания III степени на кристаллическом фундаменте Эстонии, вне зависимости от исходного состава пород, существенно каолинитовая. В менее зрелой коре встречаются также монтмориллонит-гидрослюда, гидрослюда, хлорит, монтмориллонит-хлорит, монтмориллонит.

Известно, что циркон является одним из наиболее устойчивых минералов, но в длительных постседиментационных процессах в его зернах наблюдаются некоторые характерные изменения внутреннего строения. По К. К. Жирову (1952) эти изменения заключаются в его помутнении, в появлении расплывчатых и точечных темных включений, а также ряда оптических аномалий - пониженной интерференционной окраски, неравномерного или неполного погасания минерала и т. д. Перечисленные изменения свидетельствуют о частичном или полном переходе циркона в метамиктное состояние. Большинство авторов утверждает, что этот переход происходит в результате активного физико-химического воздействия окружающей среды и представляет одну из наиболее ранних стадий 
изменения минерала вообще. К. К. Жиров ссылается на возможное увеличение интенсивности процесса метамикмитизации циркона и в коре выветривания, когда под воздействием внешних факторов создаются напряжения в кристалле и структурные связи ослабевают.

При сравнении изученных нами цирконов из «свежих» кристаллических пород и из коры выветривания выяснилось, что по внешней форме кристаллов существенных изменений не отмечается. В профиле коры выветривания, несмотря на полное преобразование валового минерального состава, циркон сохраняет основные типоморфные особенности, свойственные исходным породам. Это позволило в ряде случаев в каолинитовых продуктах III степени коры выветривания, где почти все первичные признаки выветрелых пород полностью уничтожены, восстановить тип первичной породы по определенным наборам типоморфных разновидностей циркона.

В скв. Элва (555) циркон в каолинитовых глинах верхней части коры выветривания III степени мощностью 1,6 м идентичен с цирконом из гранито-гнейсов - преобладающая масса представлена панидиоморфными, реже идиоморфными полупрозрачными кристаллами с четкой зональностью и трещиноватостью, частыми включениями, образующими оболочки на зернах более ранней генерации (реликтовый циркон). Последние встречаются как в виде ядер, так и в виде самостоятельных полупрозрачных трещиноватых кристаллов полуокругленной или округленной формы и содержат также много включений. Встречается циркон. даже из третьей генерации. Кристаллы циркона часто корродированы; метамиктны, встречаются наросты и сростки (Конса, 1986). Все это позволяет заключить, что исходной породой коры выветривания служили гранитогнейсы.

Вскрытая скважинами Ныммевески (Ф-129) и Сакусааре (Ф-136) кора выветривания в верхней части сложена более мощной (соответственно 4,9 и 8,4 м), существенно каолинитовой глиной (III степень), исходной породой для которой, судя по особенностям циркона, служат биотит-амфиболовые плагиогнейсы или амфиболиты. Преобладающая масса цирконов представлена метаморфогенными панидиоморфными полупрозрачными или прозрачными кристаллами, довольно часто зонального строения и с включениями. Реликтовые обломочные цирконы: полуокругленные, прозрачные или полупрозрачные, встречаются включения, зональность отсутствует.

Первичной породой каолинитовой коры выветривания в скв. Ф-154 следует считать по некоторым характерным чертам циркона (присутствие большого количества реликтовых окатанных зерен циркона: кристаллы со следами окатывания или окатанными ядрами) высокоглиноземистые гнейсы.

На участках с более мощной корой выветривания, например, в гнейсах алутагузеской зоны (скв. Ф-199), где мощность всей коры выветривания превышает 65 м и каолинитовая часть коры III степени выветривания составляет 26,3 м, наблюдается снизу вверх слабо выраженная тенденция к увеличению количества корродированных и затемненных метамиктовых зерен циркона с более интенсивными ожелезненными «рубашками» в кровле. Отмеченная тенденция, вероятно, связана.с длительностью процессов гипергенеза, но различить точно изменения, связанные с выветриванием, по нашему материалу в настоящей стадии изучения, еще невозможно.

Подытоживая вышеизложенное, следует подчеркнуть, что циркон в ряде случаев имеет хорошие индикаторные свойства для восстановления первичной породы также в коре выветривания высокой зрелости, где остальные первичные признаки практически полностью уничтожены. Индикаторные свойства типоморфных особенностей циркона являются 
весьма устойчивыми также в цикле гипергенного разложения материнских пород при выветривании. Это позволяет их использовать и для решения некоторых более широких геологических проблем, в частности для установления источников сноса терригенного материала и роли унаследованности минералогических ассоциаций в базальных отложениях венда и кембрия на южном склоне Балтийского щита (Вийдинг, Конса, 1976; Конса, Вийдинг, 1983).

\section{ЛИТЕРАТ УРА}

Ванамб В., Кууспалу $T$., Утсал $K$. О минералогической зональности коры выветривания кристаллического фундамента Эстонии. - Уч. зап. ТГУ, вып. 359. Тр. по геол. VIII. 1977, 71-103.

Buйдинг X., Конса $M$. Учет данных по типоморфным разновидностям минералов терригенных отложений. - В сб.: Методика и интерпретащия результатов минералогических и геохимических исследованнй. Вильнюс, 1976, 60-67.

Жиров К. K. О переходе циркона в метамиктное состояние. - ДАН СССР, 1952, 85, № 4, 889-891.

Конса М. И. Типоморфные особенности циркона пород кристаллического фундамента Эстонии. - Изв. АН ЭССР. Геол., 1986, 35, № 1, $1-9$.

Конса М. И., Вийдинг X. A. Проблема унаследованности минерального состава терригенных отложений (на примере сравнительного изучения коры выветривания кристаллического фундамента и базальных осадочных пород). - В кн.: Терригенные минералы осадочных пород Прибалтики. 1983, 41-49.

Кристаллический фундамент Эстонии. М., 1983, 173.

Кууспалу T., Ванамб В., Утсал К. О минералогии коры выветривания кристаллического фундамента Әстонии. - Уч. зап. ТГУ, вып. 286. Тр. по геол. 1971, 52-163.
Институт геологии
Академии наук Эстонской ССР
Поступила в редакцию
$18 / \mathrm{IV} 1985$

$\begin{array}{cc}\text { Институт геологии } & \text { Поступила в редакцию } \\ \text { Академии наук Эстонской ССР } & 18 / \mathrm{IV} 1985\end{array}$

Mare KONSA

\section{TSIRKOON EESTI KRISTALSE ALUSKORRA VENDIEELSES MURENEMISKOORIKUS}

Uurimus käsitleb tsirkooni Eesti kristalse aluskorra murenemiskoorikus, kus tema väliskuju ja siseehituse olulised tunnused säilitavad lähtekivimitele iseloomulikud jooned, vōimaldades kindlaks teha viimaste koostise ka III astmeni murenenud, peaaegu ainult kaoliinsavidega esindatud murenemiskooriku ülemises osas, kus muud kriteeriumid puuduvad.

\section{Mare KONSA}

\section{ZIRCON IN PRE-VENDIAN WEATHERING RIND OF ESTONIAN CRYSTALLINE ROCKS}

The study of 45 samples from 15 borehole sections of Estonian pre-Vendian weathering rind confirmed that zircon, being one of the most weathering-stable minerals, has preserved the outline of crystals and typomorphic features of the corresponding type of the underlying crystalline rocks. Using zircon as an indicator, the type of primary rocks was established in the sections lacking other primary features. Zircon is stable in long-term weathering processes and can be used for the identification of the sources of terrigenous material and the origin of mineral associations in basal layers of Vendian and Cambrian sedimentary rocks on the southern slope of the Baltic shield. 